\title{
Whey Starter for Grana Padano Cheese: Effect of Technological Parameters on Viability and Composition of the Microbial Community
}

\author{
M. Santarelli, ${ }^{\star}$ M. Gatti, ${ }^{\star 1}$ C. Lazzi, ${ }^{*}$ V. Bernini, ${ }^{*}$ G. A. Zapparoli, $\dagger$ and E. Neviani ${ }^{\star}$ \\ *Department of Genetics, Biology of Microorganisms, Anthropology, Evolution, University of Parma, 43100 Parma, Italy \\ †Ente Regionale per i Servizi all'Agricoltura e alle Foreste, Sezione di Mantova, 46010 Mantova Italy
}

\begin{abstract}
This work aimed to investigate the effects of thermal treatments and yeast extract addition on the composition of the microbial community of natural whey starters for Grana Padano cheese. Different natural whey starter samples were held at $4^{\circ} \mathrm{C}$ for $24 \mathrm{~h}$ (cooling treatment), or at $-20^{\circ} \mathrm{C}$ for $24 \mathrm{~h}$ (freezing treatment) to evaluate the possibility of conservation, or at $54^{\circ} \mathrm{C}$ for $1 \mathrm{~h}$ (heat treatment) to evaluate the effect of the temperature commonly used during curd cooking. Separately, another set of samples was enriched with $0.3,0.5$, and $1.0 \%$ (wt/vol) of yeast extract to study its effect on the growth of lactic acid bacteria (LAB) in the starter. The new approach in this study is the use of 2 culture-independent methods: length heterogeneity (LH)-reverse transcription (RT)PCR and fluorescence microscopy. These techniques allowed us to easily, quickly, and reproducibly assess metabolically active LAB in the control and treated samples. The LH-RT-PCR technique distinguished microorganisms based on natural variations in the length of $16 \mathrm{~S}$ rRNA amplified by RT-PCR, as analyzed by using an automatic gene sequencer. Fluorescence microscopy counts were performed by using a Live/Dead BacLight bacterial viability kit. The repeatability of LH-RT-PCR showed that this technique has great potential to reveal changes in the microbial community of natural whey starters for Grana Padano cheese. All species showed low sensitivity to cold $\left(4^{\circ} \mathrm{C}\right)$. However, after the freezing $\left(-20^{\circ} \mathrm{C}\right)$ and heating $\left(54^{\circ} \mathrm{C}\right)$ treatments, different behaviors of the species were reported, with significant changes in their viability and relative composition. Heating treatment during curd cooking profoundly affected the viability and composition of the community that remained in the cheese and that consequently modified the microbial population. At the same time, this treatment produced the selection of LAB in whey and could be considered as the first step in natural whey starter pro-
\end{abstract}

Received April 20, 2007.

Accepted November 20, 2007.

${ }^{1}$ Corresponding author: monica.gatti@unipr.it duction. Addition of yeast extract stimulated the growth of Streptococcus thermophilus and Lactobacillus delbrueckii ssp. lactis to the detriment of Lactobacillus helveticus species. Because the yeast extract altered the microflora balance, whey starter conservation at $-20^{\circ} \mathrm{C}$ and yeast extract addition cannot be suggested as technological innovations.

Key words: natural whey starter, Grana Padano cheese, length heterogeneity-reverse transcription-polymerase chain reaction, fluorescence microscopy

\section{INTRODUCTION}

The natural whey starter used in the production of Grana Padano cheese is a complex microbial association of lactic acid bacteria (LAB), not only because of the presence of various species, but also because of the large number of biotypes (Giraffa et al., 1997). It is obtained from the previous day's cheese-making whey (named sweet whey) incubated at a decreasing temperature, favoring the growth of a large number of viable thermophilic LAB (Mucchetti and Neviani, 2006). Different studies have been carried out to characterize the natural whey microflora, which are mainly composed of homofermentative thermophilic lactobacilli (e.g., Lactobacillus helveticus, Lactobacillus delbrueckii ssp. lactis) and a minor variable presence of heterofermentative lactobacilli (Lactobacillus fermentum) and Streptococcus thermophilus (Beresford et al., 2001; Mucchetti and Neviani, 2006). Understanding the dynamics of such communities is very laborious and time-consuming. Moreover, the inability to cultivate more than a small proportion of the bacteria that can be visualized by direct count procedures makes it difficult to obtain information on the entire microbial community (Head et al., 1998; Marsh 1999). Thus, to study interactions among microorganisms, it is important to study the ecosystem without dissociating it. Culture-independent approaches, such as those involving PCR, provide new insight by helping to define the biodiversity of communities and permitting the detection of viable, nonviable, and viable but noncultivable populations. 
Various PCR-based molecular typing methods have been developed for the analysis of populations, including denaturing gradient gel electrophoresis, temperature gradient gel electrophoresis, single-strand conformation polymorphism, and temporal temperature gel electrophoresis, that provide a rapid, yet good representative fingerprint of the microbial community structure without cultivation (Coppola et al., 2001; Ercolini et al., 2002; Duthoit et al., 2003; Hori et al., 2006). An increasing number of new methodologies incorporate automatic sequencing systems for laser detection of fluorescently labeled DNA fragments. The most common are terminalrestriction fragment length polymorphism (Marsh 1999; Osborn et al., 2000; Sánchez et al., 2006) and length heterogeneity-PCR (LH-PCR) analysis (Suzuki et al., 1998). Length heterogeneity-PCR analysis distinguishes different organisms based on natural variations in the length of $16 \mathrm{~S}$ ribosomal DNA sequences (Ritchie et al., 2000). Fluorescent end-labeled PCR products are separated by capillary electrophoresis and detected by laserinduced fluorescence with an automated gene sequencer. The subsequent analysis of the relative amounts of amplified sequences originating from different microorganisms can then be made (Suzuki et al., 1998). Use of the LH-PCR method has been more limited than terminalrestriction fragment length polymorphism analysis in studies on microbial diversity. To date, it has been used to study microbial communities in aquatic environments (Suzuki et al., 1998), soil (Ritchie et al., 2000), and maize silage (Brusetti et al., 2006), and, in a few studies, on food-associated ecosystems such as dairy (Lazzi et al., 2004; Fornasari et al., 2006). Discriminating viable from dead cells is of importance in the development of bacterial detection methods. Recently, the effectiveness of the fluorescence microscopy technique to evaluate microbial viability was demonstrated in natural whey starter for Grana Padano cheese (Gatti et al., 2006). This technique allows the detection of microbial cells directly from their environment without any previous isolation step. Microbial cell viability is correlated with the physiological activity of a cell (Breeuwer and Abee, 2000). A disadvantage of DNA-based methods is that they do not distinguish between viable and nonviable cells. The DNA from lysed cells can persist for a long time in the environment; detection of RNA would help to determine the viability of the microorganisms because RNA is degraded rapidly upon cell death. Detection of $16 \mathrm{~S}$ rRNA by reverse transcription-PCR (RT-PCR) is considered to be a useful indicator of viability (Bentsink et al., 2002; Wolffs et al., 2005). Ritchie et al. (2000) demonstrated that the LHPCR technique was effective for measurement of the microbial community composition of soil.

This work aimed to investigate the effects of technological parameters on the microbial community of natural whey starter for Grana Padano cheese by using 2 culture-independent approaches directly on samples, avoiding classical undirected microbiological techniques. To test the reproducibility and suitability of the LHRT-PCR method for assessing the microbial community structure in natural whey starters, we evaluated the variability at RT-PCR amplification and electrophoresis run levels.

A study of heating at cook temperature $\left(+54^{\circ} \mathrm{C}\right)$ was done to investigate the effect on the microbial community during curd cooking as used in Grana Padano cheese manufacture. Study of cooling $\left(+4^{\circ} \mathrm{C}\right)$ and freezing $\left(-20^{\circ} \mathrm{C}\right)$ was performed to evaluate the possibility of conserving natural whey starter at low temperatures. Furthermore, the effect of adding different amounts of yeast extract to the sweet whey was evaluated with the aim of studying the possibility of using a growth stimulator.

\section{MATERIALS AND METHODS}

\section{Natural Whey Starter Treatments}

Ten natural whey starter samples from different Grana Padano dairies were analyzed. Immediately after collection, samples were cooled at $4^{\circ} \mathrm{C}$, maintained in ice containers, and immediately after their arrival to the laboratory, were aliquoted and analyzed.

The following treatments were applied to several natural whey starters: 1) 3 samples were held at $4^{\circ} \mathrm{C}$ for 24 $\mathrm{h}$ (cooling treatment), 2) 2 samples were held at $-20^{\circ} \mathrm{C}$ for $24 \mathrm{~h}$ (freezing treatment), and 3) 2 samples, previously brought to $\mathrm{pH} 6.4$ with $10 \mathrm{M} \mathrm{NaOH}$, were held at $54^{\circ} \mathrm{C}$ for $1 \mathrm{~h}$ (heat treatment) in a water bath. Moreover, 3 samples of sweet whey (i.e., a part of the whey collected from the vat immediately after curd extraction during the cheese-making process) were enriched with 3 different concentrations $(0.3,0.5$, and $1 \%, \mathrm{wt} / \mathrm{vol})$ of yeast extract (Oxoid, Garbagnate Milanese, Italy) as a microbial growth-stimulator factor. For natural whey starter preparation, sweet whey enriched samples, and not enriched samples used as a control, were incubated at $45^{\circ} \mathrm{C}$ until the acidity reached a value of $32^{\circ} \mathrm{SH}$ (SoxhletHenkel degrees)/50 mL. All whey cultures were subjected to viable cell counts by fluorescence microscopy and RNA extraction. Frozen whey starters $(24 \mathrm{~h}$ at $-20^{\circ} \mathrm{C}$ ) were previously thawed at $37^{\circ} \mathrm{C}$ for $1 \mathrm{~min}$.

\section{Fluorescence Microscopy}

Cell viability was estimated as indicated by Gatti et al. (2006). Fluorescence microscopy counts were performed by using a Leica DMSL fluorescent microscope (Leica Microsystems, Wetzlar, Germany) provided with a mercury vapor source $(100 \mathrm{~W})$ and a fluorescein isothiocyanate filter (Leica Microsystems). A Live/Dead Bac- 
Light bacterial viability kit (Molecular Probes, Eugene, OR) was used (SYTO 9 and propidium iodide). Volumes of $0.7 \mu \mathrm{L}$ of SYTO 9 and $1 \mu \mathrm{L}$ of propidium iodide were added to $1 \mathrm{~mL}$ of second-diluted natural whey starter that had previously been washed twice with sterilized distilled water $\left(7,000 \times g\right.$ for $4 \mathrm{~min}$ at $\left.4^{\circ} \mathrm{C}\right)$. After $15 \mathrm{~min}$ at $25^{\circ} \mathrm{C}, 10 \mu \mathrm{L}$ of this suspension was placed in a Thoma Glass chamber (Electron Microscopic Sciences, Hatfield, PA). Results were expressed as percentages of viable and nonviable cells.

\section{Total RNA Extraction from Whey Starter}

Assessment of the viable microbial populations of natural whey starters for Grana Padano cheese was carried out by analysis of $16 \mathrm{~S}$ rRNA. Microbial cells from whey starters $(1 \mathrm{~mL})$ were harvested by centrifugation (at $7,000 \times g$ for $10 \mathrm{~min}$ at $4^{\circ} \mathrm{C}$ ), and pellets were washed twice in $1 \mathrm{~mL}$ of TE buffer (0.01 $M$ Tris-HCl, $0.001 M$ EDTA, pH 7.5). Pellets were then resuspended in 100 $\mu \mathrm{L}$ of TES buffer [50 $\mathrm{m} M$ Tris, $1 \mathrm{~m} M$ EDTA, $20 \mathrm{~g} / \mathrm{L}$ of lysozyme, $6.7 \%$ (wt/vol) sucrose, $\mathrm{pH} 8.0$ ] and incubated at $37^{\circ} \mathrm{C}$ for $30 \mathrm{~min}$. Extraction of RNA was performed as previously described (Fornasari et al., 2006). Pellets were dried and dissolved in $60 \mu \mathrm{L}$ of diethyl pyrocarbonate-treated water. Digestion of contaminating DNA was performed with $5 \mathrm{U}$ of amplification grade DNase I (Sigma Aldrich, Milan, Italy) under conditions given by the supplier. The quantity and purity of RNA were assessed by optical density at 260 and $280 \mathrm{~nm}$. Purified RNA extracts were diluted up to $100 \mathrm{ng} / \mu \mathrm{L}$ and stored at $-80^{\circ} \mathrm{C}$ until use.

\section{LH-RT-PCR}

Domain A of the variable region of the 16S rRNA gene was reverse transcribed and amplified, and RT-PCR products originating from different species were subsequently analyzed by an automatic gene sequencer.

RT-PCR Amplification. One-step RT-PCR was performed with a Gene Amp EZ rTth RNA PCR Kit (Applera, Italy). Primers 63F and 355R were used (Lazzi et al., 2004), with the forward primer $5^{\prime}$ end labeled with a phosphoramidine cyanine dye, Cy5. The reactions and amplification conditions were as described by Fornasari et al. (2006). Reverse transcription-PCR products were stored at $-20^{\circ} \mathrm{C}$ in the dark until use (usually less than $1 \mathrm{wk})$. Concentrations were estimated after electrophoresis in an agarose gel stained with ethidium bromide and compared with GeneRuler 100 bp DNA Ladder Plus (MBI Fermentas, M-Medical, Cornaredo, Italy) according to the manufacturer's instructions.

LH-RT-PCR Analysis. Reaction mixtures containing $12.5 \mathrm{ng}$ of RT-PCR products, $40 \mu \mathrm{L}$ of deionized for- mamide (Beckman Coulter, Cassina de Pecchi, Italy), and $0.5 \mu \mathrm{L}$ of CEQ DNA Size standard Kit 400 (Beckman Coulter) labeled with CEQ WellRED fluorescent dye, were prepared according to the manufacturer's instructions. The sample mixtures were separated by capillary electrophoresis on a CEQ 2000 DNA analysis system (Beckman Coulter) with Fragment Analysis 8000 software (Beckman Coulter). Runs were performed under denaturing conditions. The fragment analysis software converted fluorescence data into electropherograms; the peaks represented fragments of different sizes and the areas under the peaks were the relative proportions of the fragments. Fragment lengths (base pairs) were estimated by using the size standard and local Southern methods. The unknown peaks above 3,000 relative fluorescence units were considered for the analysis.

\section{Repeatability of LH-RT-PCR}

To test the reproducibility and suitability of the LHRT-PCR method for the microbial community structure in natural whey starters, we evaluated the variability present in 2 steps of the LH-RT-PCR analysis, the PCR amplification and fragment analysis levels. The analysis compared the LH-PCR results at each level in triplicate samples. In the former case, it was compared with the LH-RT-PCR results obtained from 3 separate RT-PCR amplification experiments of the one total RNA extracted. In the latter case, it was compared with the LHRT-PCR results obtained from 3 different electrophoresis runs from a single RT-PCR amplification product. The reproducibility at each level of analysis was evaluated by comparing coefficients of variation $(\mathbf{C V})$ of the relative peak areas corresponding to each species present in whey starter. These allowed us to recognize the degree of variability of these 2 levels and to compare this with the natural variability present in the natural whey starter samples.

\section{RESULTS AND DISCUSSION}

\section{Repeatability of LH-RT-PCR}

The lengths of domain A of the species considered in this study were established by reference to the LH-PCR database obtained by Lazzi et al. (2004), who investigated the LH-PCR DNA profiles of the most representative LAB species usually present in natural whey starters. Conversely, the LH-RT-PCR amplicons originating from total RNA were compared, allowing the assessment of the metabolically active microbial population of natural whey starter cultures. According to the published LH-PCR database (Lazzi et al., 2004; Fornasari et al., 2006), the presence of $S$. thermophilus, L. delbrueckii ssp. lactis, and L. helveticus species has been revealed 
Table 1. Comparison of variability at reverse transcription-PCR (RT-PCR) amplification and electrophoresis run levels, representing length heterogeneity-RT-PCR results in 3 replicates at each level

\begin{tabular}{|c|c|c|c|c|c|c|}
\hline \multirow[b]{2}{*}{ Species } & \multicolumn{3}{|c|}{ Triplicate amplification ${ }^{1}$} & \multicolumn{3}{|c|}{ Triplicate electrophoresis runs ${ }^{2}$} \\
\hline & Mean & SD & $\% \mathrm{CV}$ & Mean & SD & $\% \mathrm{CV}$ \\
\hline Streptococcus thermophilus ${ }^{3}$ & 0.08 & 0.033 & 42.0 & 0.11 & 0.010 & 8.6 \\
\hline Lactobacillus delbrueckii ssp. lactis ${ }^{4}$ & 0.29 & 0.034 & 11.5 & 0.31 & 0.058 & 18.6 \\
\hline Lactobacillus helveticus ${ }^{5}$ & 0.63 & 0.005 & 0.8 & 0.57 & 0.068 & 11.8 \\
\hline
\end{tabular}

${ }^{1}$ Mean of relative peak area in triplicate RT-PCR amplifications from the same sample.

${ }^{2}$ Mean of relative peak area in triplicate runs from the same sample.

${ }^{3}$ Fragment length $319 \pm 1$ (bp).

${ }^{4}$ Fragment length $331 \pm 1(\mathrm{bp})$.

${ }^{5}$ Fragment length $334 \pm 1(\mathrm{bp})$.

by fragments of $320 \pm 1,330 \pm 1$, and $334 \pm 1 \mathrm{bp}$, respectively. Two fragments of $342 \pm 1$ and $345 \pm 1$ bp revealed the presence of Lactobacillus fermentum species. In agreement with Cocconcelli et al. (1997), Lazzi et al. (2004), and Fornasari et al. (2006), we found that the microbial composition of natural whey starters showed a constant presence of dominant species corresponding to L. helveticus and L. delbrueckii ssp. lactis, and minor species corresponding to $S$. thermophilus and L. fermentum.

One of the concerns of the PCR-based methods is the introduction of bias by PCR (Suzuki et al., 1998). Ritchie et al. (2000) determined which step in the LH-PCR procedure resulted in the greatest variability. In this work, the repeatability test was carried out by comparing the percentage CV of the relative peak areas of the RT-PCR amplicons at each level of analysis (Table 1). As reported by Suzuki et al. (1998), the relative proportion of each component of the population can then be measured. The relative peak areas were calculated as the ratio between an individual peak area and the total peak area (sum of the areas of all peaks). The greatest amount of variability among species was at the RT-PCR amplification level (CV range of 0.8 to $42 \%$ ), and in particular, less abundant components exhibited greater CV values. Moreover, the electrophoresis runs showed similar variability among species (CV range of 8.6 to $18.6 \%$ ) and the variability was not correlated with relative abundance. Lactobacillus helveticus and L. delbrueckii ssp. lactis appeared to be more reproducible than $S$. thermophilus. In agreement with Fisher and Triplett (1999), fragment relative abundance appeared to be the most reproducible for those peaks that contributed the greatest amount to total fluorescence. For this reason, any conclusion regarding the relative abundance of less abundant components should be made carefully.

\section{Comparison of Different Whey Starters}

All whey starter samples showed the presence of $L$. helveticus, L. delbrueckii ssp. lactis, and S. thermophilus, but only 4 samples showed the presence of $L$. fermentum . These results agreed with those of other authors who found the composition of the culture to be dominated by $L$. helveticus, with a minor presence of $L$. delbrueckii ssp. lactis and $S$. thermophilus and the nondominant bacterial population of $L$. fermentum (Beresford et al., 2001). The relative abundances of the viable microbial populations from 10 different natural whey starters for Grana Padano cheese and their viabilities are illustrated in Figure 1.

The variability of the 3 species at each level of analysis was smaller than the variability observed in the 10 whey starters analyzed (Table 2). For this reason, the LH-RTPCR technique can be considered an effective tool for assessing the composition of the viable microbial community in natural whey starters for Grana Padano cheese.

None of the whey starter samples analyzed showed great diversity in its composition, and all were constituted from 3 or 4 species. However, the percentage of each species in each sample was different. Figure 1A shows the relative abundance of the metabolically active species calculated as previously described. The main species was L. helveticus, which ranged between 60 and $80 \%$ in all the whey starters studied. Greater variability was found in L. delbrueckii ssp. lactis species (between 10 and $42 \%$ ) and S. thermophilus (between 1 and 20\%).

Figure 1B shows the percentages of viable and nonviable populations, yielding variable but highly viable fraction values (between 73 and 99\%) as expected. This result agrees with the natural whey starter characteristic of being composed mainly of viable bacterial populations, except for one sample, $G$, which showed similar viable and nonviable fractions.

\section{Assessment of Natural Whey Starter Treatments}

Knowledge of the effects of different thermal stresses on the equilibrium of the natural whey starter microflora is an important feature. It permits an understanding of the interaction among different species during storage at different temperatures and during curd cooking. 
$\mathbf{A}$

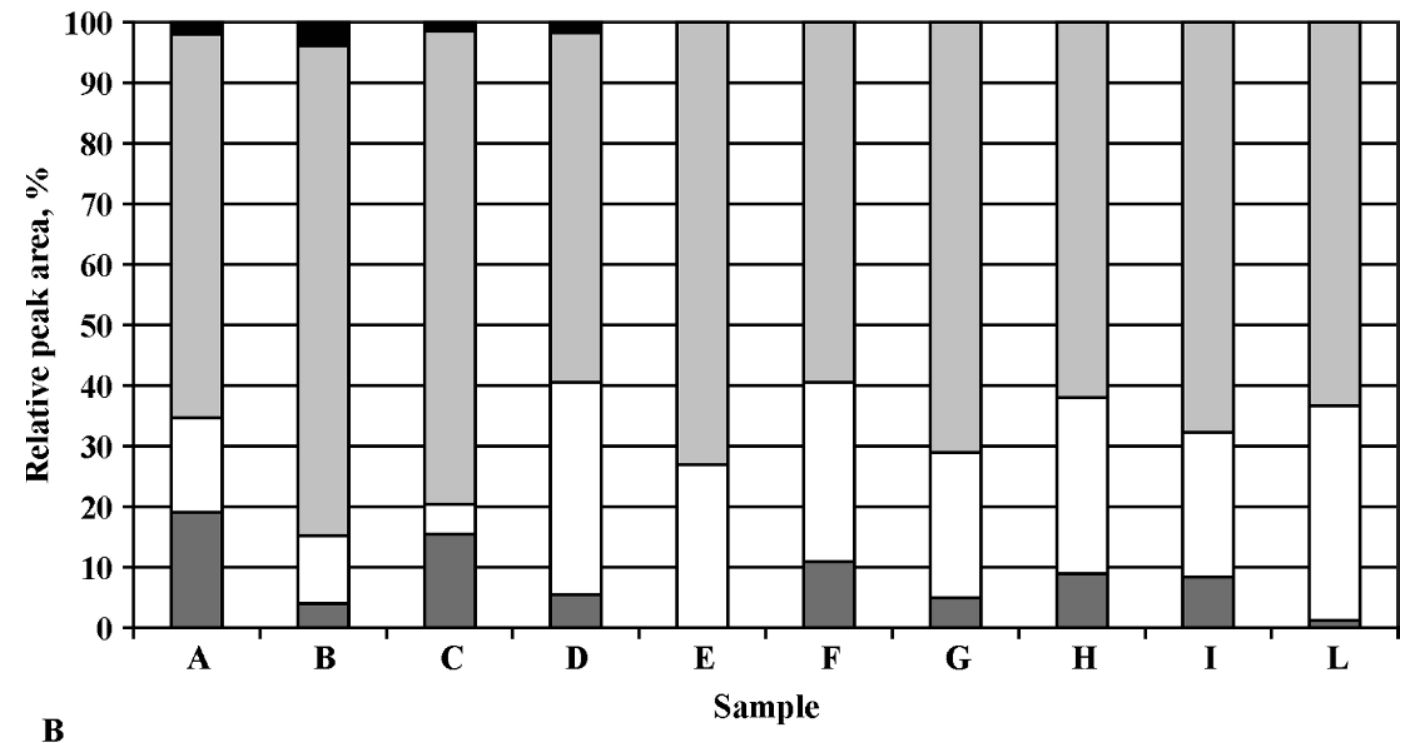

B

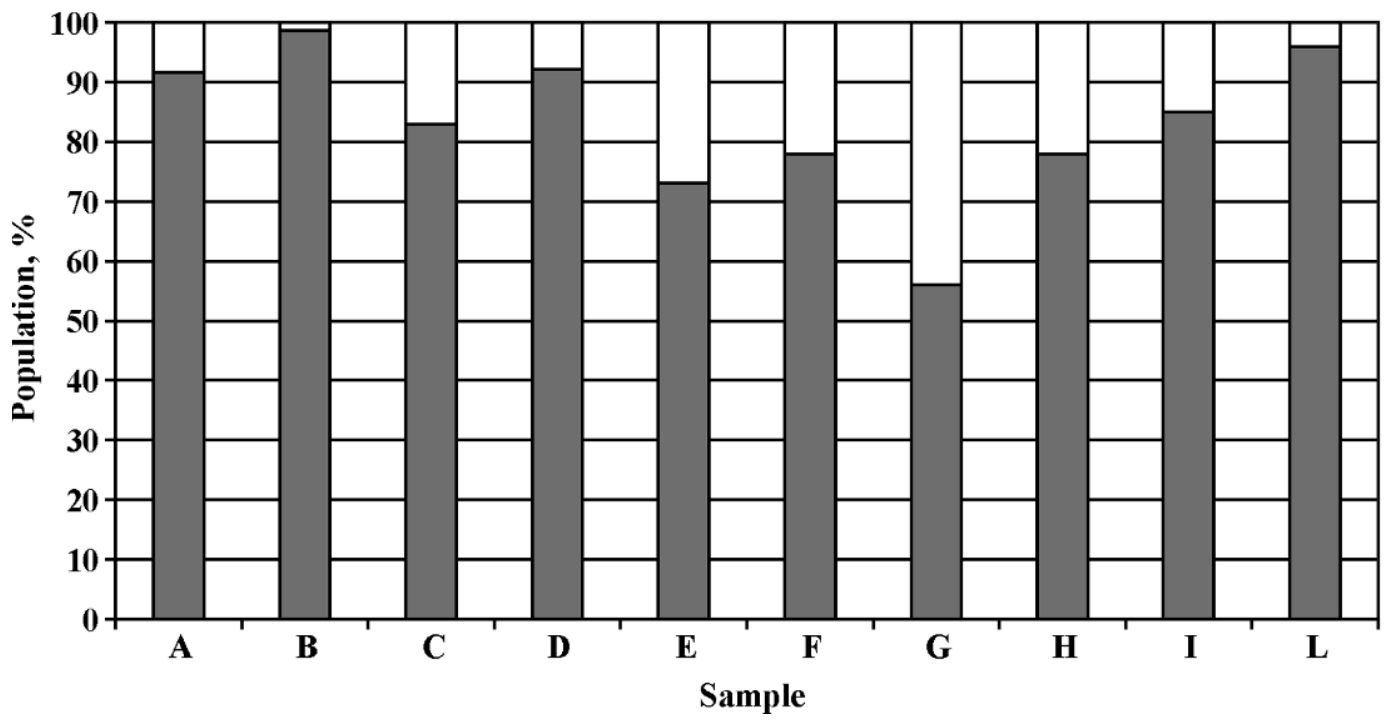

Figure 1. Comparison of natural whey starters from different Grana Padano cheese dairies. The $x$-axis represents the whey samples (A to L). Panel A) Length heterogeneity-reverse transcription-PCR results: the y-axis represents the percentages of the relative peak areas corresponding to Lactobacillus helveticus (gray), Lactobacillus delbrueckii ssp. lactis (white), Streptococcus thermophilus (dark gray), and Lactobacillus fermentum (black). Panel B) Fluorescence microscopy counts: the y-axis represents the percentages of viable (white) and nonviable (dark gray) populations.

Cooling and Freezing Treatment. Results of this study showed that cooling for $24 \mathrm{~h}\left(4^{\circ} \mathrm{C}\right)$ did not considerably affect the percentage of the species $L$. delbrueckii ssp. lactis, whereas L. helveticus and S. thermophilus showed decreased and increased percentage values, respectively. Nevertheless, such variations were within the range of variability found in both control and cooled whey samples (3 repetition), as shown in the standard deviation bars in Figure 2. Percentage of viable cells in the samples cooled for $24 \mathrm{~h}\left(4^{\circ} \mathrm{C}\right)$ was lower and less variable than that evaluated in fresh ones.

In agreement with Kim and Dunn (1997), whey starters subjected to freezing temperatures showed a drastic decrease in cell viability. The freezing treatment at $-20^{\circ} \mathrm{C}$ was found to damage the viability of cells, causing a decrease in the mean percentage values from $83 \%$ (more variable) in fresh samples to $33 \%$ (less variable) in frozen whey samples, respectively (Figure 3). In com- 
Table 2. Amount of variability in 10 whey starters analyzed

\begin{tabular}{llcc}
\hline & \multicolumn{3}{l}{ Values of relative peak area } \\
\cline { 2 - 4 } Species & $\mathrm{Mean}^{1}$ & $\mathrm{SD}$ & $\% \mathrm{CV}$ \\
\hline Streptococcus thermophilus & \\
Lactobacillus delbrueckii $^{2}$ sp. lactis $^{3}$ & 0.093 & 0.050 & 54.9 \\
Lactobacillus helveticus $^{4}$ & 0.23 & 0.096 & 41.6 \\
\hline
\end{tabular}

${ }^{1}$ Mean value of relative peak areas from 10 whey starter controls analyzed.

${ }^{2}$ Fragment length $319 \pm 1$ (bp).

${ }^{3}$ Fragment length $331 \pm 1$ (bp).

${ }^{4}$ Fragment length $334 \pm 1$ (bp).

paring the composition of the fresh control and frozen whey samples, a different behavior of the population was found. There was a relative decrease in $L$. delbrueckii ssp. lactis species and a relative increase in the $L$. helveticus population in frozen wheys. Streptococcus thermophilus species did not show great variations (Figure 2 ). The frozen tolerance of $L$. helveticus found in this study agrees with the report of Gómez Zavaglia et al. (2000), who, through a study of fatty acid composition and freeze-thaw resistance, concluded that $L$. helveticus species, with a low concentration of unsaturated fatty acids (42 to $49 \%$ ) and high fatty acid $\mathrm{C}_{19}$ cyclopropane (cyc19:0) levels, were associated with an increase in freeze-thaw resistance. In contrast with $L$. delbrueckii ssp. lactis, which has a high content of unsaturated fatty acids (66 to 70\%), the resistance decreased with the increase in fatty acid $\mathrm{C}_{19}$ cyclopropane (cyc19:0) concentrations. In addition, Kim and Dunn (1997) demonstrated that a cold shock at $-20^{\circ} \mathrm{C}$ for $24 \mathrm{~h}$ induced the activation of adaptive cold shock response through the csp gene, increasing the viability of $L$. helveticus. This gene was confirmed to be low temperature-induced in both $L$. helveticus (Kim and Dunn, 1997) and S. thermophilus species (Wouters et al., 1999; Varcamonti et al., 2006). Moreover, Varcamonti et al. (2006) suggested that the heat shock gene $c l p L$ of $S$. thermophilus was induced by both heat and cold shock.

Heating Treatment. Heating at $54^{\circ} \mathrm{C}$ for $1 \mathrm{~h}$ allowed us to simulate the effect of curd cooking on thermophilic LAB in the natural whey starter population used in Grana Padano cheese technology. For this reason, before heating, the samples were brought to $\mathrm{pH} 6.4$, the typical $\mathrm{pH}$ value of the curd in the vat (Mucchetti and Neviani, 2006). Natural whey starter was obtained from the sweet whey collected after curd cooking and incubated at a decreasing temperature. All natural whey starters are subjected to this treatment in their preparation. In agreement with a recent exhaustive study by Sheehan et al. (2007), after the heating treatment, the cell viability and the relative species composition were modified as expected. The ratio of viable to nonviable populations was inverted from 83:17 in control samples to 20:80 in heated samples $\left(54^{\circ} \mathrm{C}\right.$ for $1 \mathrm{~h}$; Figure 3$)$. Species showed

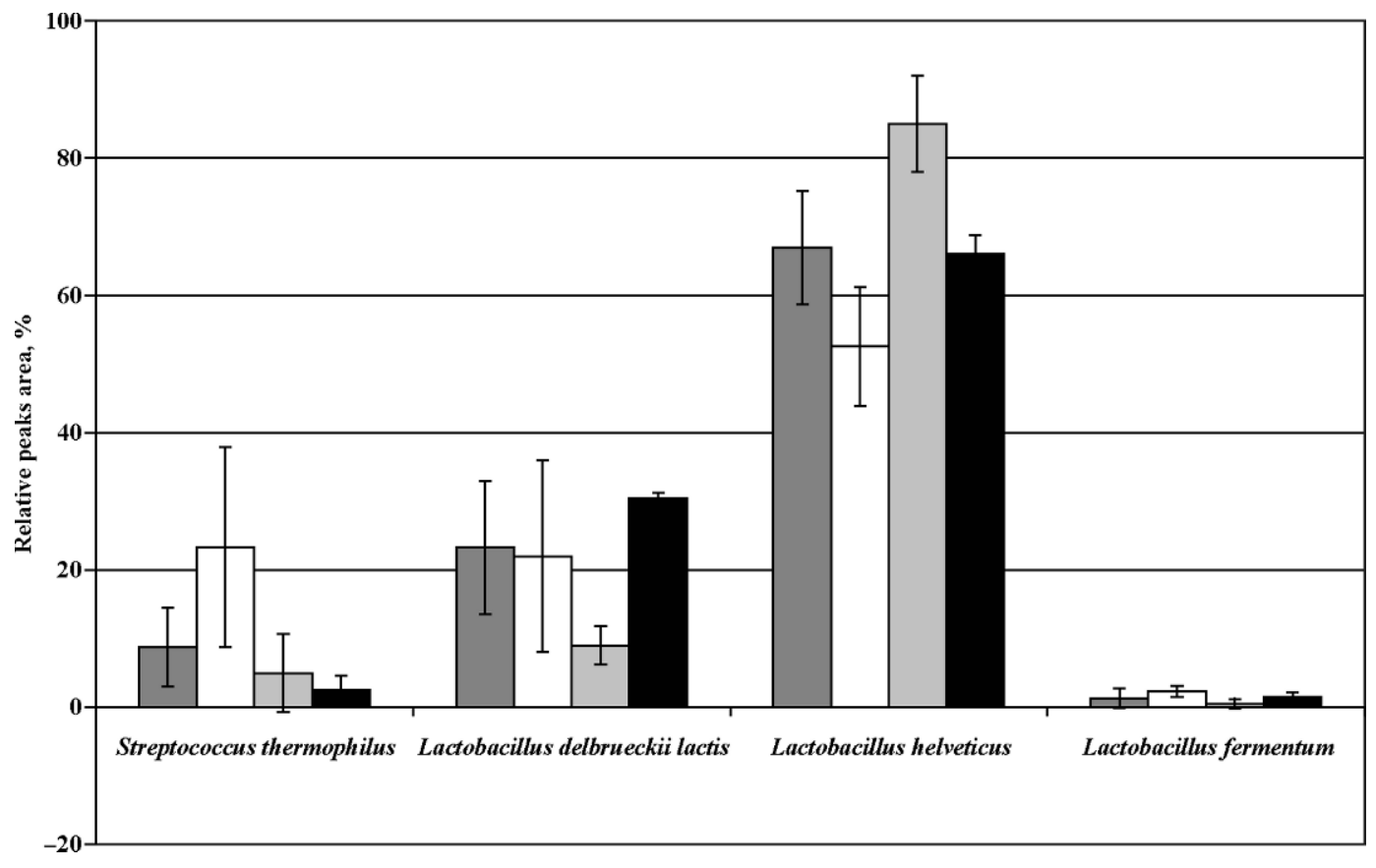

Figure 2. Comparison of whey starter treatments. The y-axis represents the relative peak area of the species from fresh whey starters (dark gray) and whey starters subjected to different thermal stresses: $24 \mathrm{~h}$ at $4^{\circ} \mathrm{C}$ (white), $24 \mathrm{~h}$ at $-20^{\circ} \mathrm{C}$ (gray), and $1 \mathrm{~h}$ at $54^{\circ} \mathrm{C}$ (black). Error bars indicate standard deviation from $3\left(4^{\circ} \mathrm{C}\right)$ or $2\left(-20\right.$ and $\left.54^{\circ} \mathrm{C}\right)$ experiments. 
different responses to heat; the most tolerant was the L. delbrueckii ssp. lactis species (Figure 2). As expected, this treatment completely changed the cell viability by reducing the number of viable cells, and interestingly, it also modified the proportions of microbial species, which will remain either in the curd or in the collected sweet whey incubated at a decreasing temperature to obtain the following day's whey starter.

Cook temperature may cause changes not only in the curd, which will be converted into cheese in the subsequent step of the cheese-making process (Sheehan et al., 2007), but also in the sweet whey used for Grana Padano cheese production, which is subsequently incubated at a decreasing temperature to reach an acidity ranging from 28 to $32^{\circ} \mathrm{SH} / 50 \mathrm{~mL}$ for natural whey starter preparation (Mucchetti and Neviani 2006). Studies on heat tolerance carried out on $L$. delbrueckii ssp. bulgaricus indicated that variants with higher heat resistance could be selected (Gouesbet et al., 2002). The authors demonstrated that enhanced viability, observed after $10 \mathrm{~min}$ at $65^{\circ} \mathrm{C}$, resulted from the overexpression of heat shock proteins. Results of this study showed that, in spite of a reduction in total cell viability, $L$. delbrueckii ssp. lactis, which is phylogenetically related to $L$. delbrueckii ssp. bulgaricus, showed a higher heat tolerance than the others. Guerzoni et al. (2001) showed that after a heating treatment at $54^{\circ} \mathrm{C}$, the increase in unsaturated fatty acids in the cell membrane was a general response of $L$. helveticus when exposed to superoptimal temperatures, and in combination with other stresses. Nevertheless, as shown in this study, such resistance did not seem high enough to maintain $L$. helveticus in balance with the other species.

Growth-Stimulator Factor Assessment. The main role of natural whey starter is to produce acid at a consistently fast rate through the manufacturing period each and every day. To reach this goal, the cells should be numerous, viable, and able to replicate in the vat milk. Nowadays, natural whey starter preparation is still traditional and empirical. The possibility of improving bacterial growth could shorten and standardize preparation time and increase cell viability. In this study, we evaluated the effect of adding different concentrations of yeast extract to the sweet whey to investigate the possibility of using it as a microbial growth stimulator.

The addition of $0.3 \%(\mathrm{wt} / \mathrm{vol})$ and $0.5 \%(\mathrm{wt} / \mathrm{vol})$ yeast extracts did not greatly change the total rate of viable and nonviable cells in the starter (Figure 4). A negative effect was caused by $1.0 \%$ addition. In this concentration, yeast extract increased the growth capacity of $S$. thermophilus and $L$. delbrueckii ssp. lactis at the expense of the L. helveticus species. The highest concentration of the product caused a complete imbalance of the whey starter composition, improving the growth of both $S$.

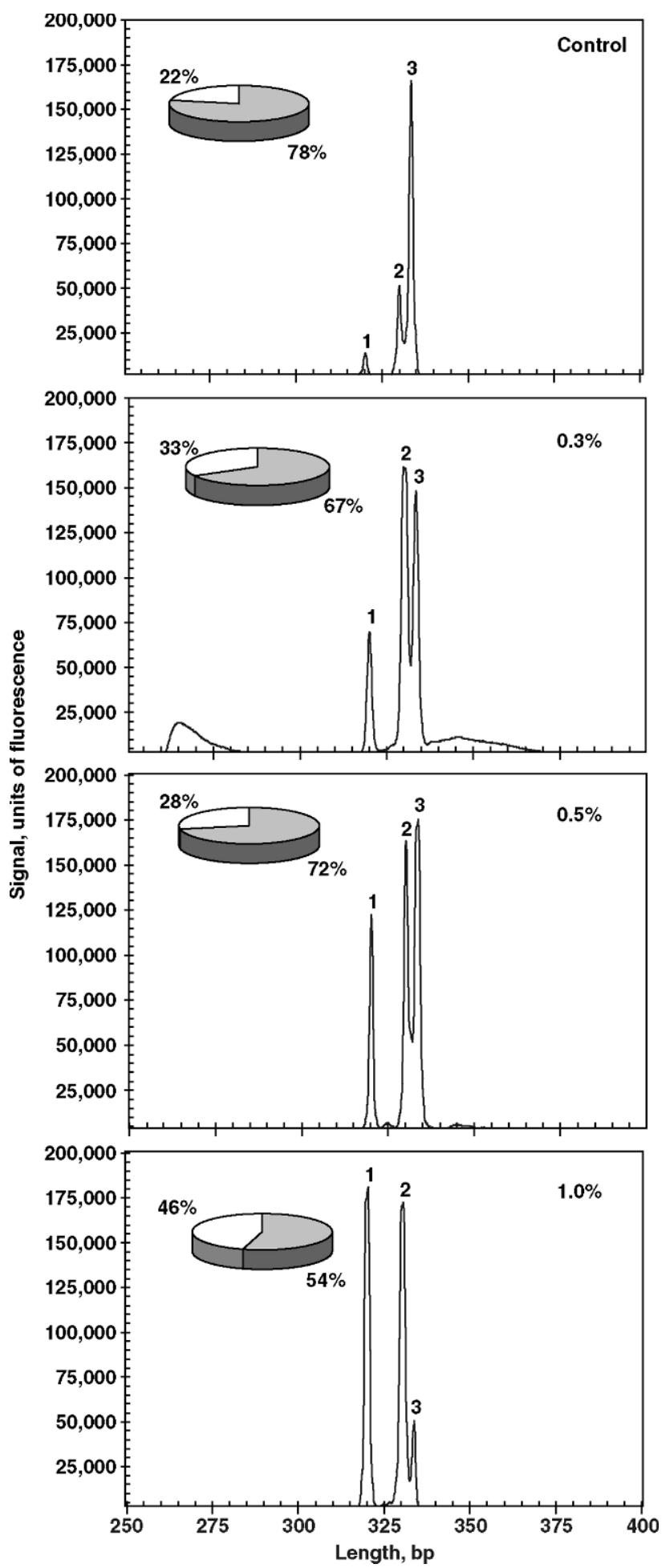

Figure 4. Length heterogeneity-reverse transcription-PCR electropherograms showing the profile obtained by analyzing the lactic acid bacteria population of Grana Padano whey starters traditionally prepared and enriched with 3 different concentrations $(0.3,0.5$, and $1 \%, \mathrm{wt} / \mathrm{vol}$ ) of yeast extract as a microbial growth-stimulator factor: Streptococcus thermophilus (1), Lactobacillus delbrueckii ssp. lactis (2), Lactobacillus helveticus (3). The pie chart represents the percentages of total viable (gray) and nonviable (white) populations. 
thermophilus and L. delbrueckii ssp. lactis species. Consequently, L. helveticus became the minor viable species, so that the composition profile of the resulting whey was completely different for all the whey starters analyzed. This result could be due to the different nutritional requirements of the species present in natural whey starters. Lactobacillus helveticus seemed to be the most adapted to this particular environment because it has the greatest capability to use whey as a complete medium. Conversely, the other species favored by yeast extract were increased considerably. Moreover, the total viability of the culture at the end of incubation was reduced, presumably because of the minor acid resistance of the new dominant species (S. thermophilus and L. delbrueckii ssp. lactis vs. L. helveticus; van de Guchte et al., 2002).

\section{CONCLUSIONS}

Length heterogeneity-RT-PCR and fluorescence microscopy techniques can be considered suitable tools to assess variations in viable microbial populations in food ecosystems, such as the natural whey starters for Grana Padano cheese. These new techniques allowed us to easily, quickly, and reproducibly assess metabolically active $\mathrm{LAB}$ and enabled a direct analysis from the sample, avoiding time-consuming classical undirected microbiological techniques. Nevertheless, this new approach requires expensive equipment and is technically demanding.

Results of this study confirmed the microbiological composition of natural whey starters and the amount of variability caused by selective pressure attributable to heating during cheese making. The species present in whey starter showed different behaviors in response to low (freezing) temperature $\left(-20^{\circ} \mathrm{C}\right)$; such variability highlights the fact that this treatment cannot be useful in preserving the microbial community balance. Because of different nutritional requirements, addition of yeast extract to sweet whey, as a growth-stimulator factor, altered the microbial balance, favoring $S$. thermophilus growth. Our results support the view that modification of the composition of sweet whey nitrogen compounds could also affect the microbial composition of the resulting natural whey starter. These technological innovations, which are not considered in the Grana Padano Production Disciplinary, modify the relative proportion of each species and its viability in the culture. Such variations could have a direct influence on the technological effectiveness of the natural whey starter, and consequently on the peculiarity of the cheese.

\section{ACKNOWLEDGMENTS}

The authors are grateful to Giorgio Giraffa (CRA Istituto Sperimentale Lattiero Caseario di Lodi, Italy) for his critical readings of the manuscript and useful suggestions. This work was partly supported by the Italian Ministry of Agriculture within the Program "Popolazione microbica in ecosistemi complessi quali i sieroinnesti naturali per la produzione di formaggi italiani" and Regione Lombardia and Consorzio Grana Padano within the Program "Il sieroinnesto naturale come coltura di microrganismi autoctoni caratteristici della produzione del formaggio Grana Padano" (SIMAGRAP).

\section{REFERENCES}

Bentsink, L., G. O. M. Leone, J. R. C. M. van Beckhoven, H. B. van Schijndel, B. van Gemen, and J. M. van der Wolf. 2002. Amplification of RNA by NASBA allows direct detection of viable cells of Ralstonia solanacearum in potato. J. Appl. Microbiol. 93:647-655.

Beresford, T. P., N. A. Fitzsimons, N. L. Brennan, and T. M. Cogan. 2001. Recent advances in cheese microbiology. Int. Dairy J. 11:259-274.

Breeuwer, P., and T. Abee. 2000. Assessment of viability of microorganisms employing fluorescence techniques. Int. J. Food Microbiol. 55:193-200.

Brusetti, L., S. Borin, D. Mora, A. Rizzi, N. Raddadi, C. Sorlini, and D. Daffonchio. 2006. Usefulness of length heterogeneity-PCR for monitoring lactic acid bacteria succession during maize ensiling. FEMS Microbiol. Ecol. 56:154-164.

Cocconcelli, P. S., M. G. Parisi, L. Senini, and V. Bottazzi. 1997. Use of RAPD and 16S rDNA sequencing for the study of Lactobacillus population dynamics in natural whey culture. Lett. Appl. Microbiol. 25:8-12.

Coppola, S., G. Blaiotta, D. Ercolini, and G. Moschetti. 2001. Molecular evaluation of microbial diversity occurring in different types of Mozzarella cheese. J. Appl. Microbiol. 90:414-420.

Duthoit, F., J. J. Godon, and M. C. Montel. 2003. Bacterial community dynamics during production of registered designation of origin Salers cheese as evaluated by $16 \mathrm{~S}$ rRNA gene single-strand conformation polymorphism analysis. Appl. Environ. Microbiol. 69:3840-3848.

Ercolini, D., G. Blaiotta, G. Moschetti, and S. Coppola. 2002. Evaluation of PCR-DGGE analysis for molecular typing of cheeses. Ann. Microbiol. 52:81-87.

Fisher, M., and E. W. Triplett. 1999. Automated approach for ribosomal intergenic spacer analysis of microbial diversity and its application to freshwater bacterial communities. Appl. Environ. Microbiol. 65:4630-4636.

Fornasari, M. E., L. Rossetti, D. Carminati, and G. Giraffa. 2006. Cultivability of Streptococcus thermophilus in Grana Padano cheese whey starters. FEMS Microbiol. Lett. 257:139-144.

Gatti, M., V. Bernini, C. Lazzi, and E. Neviani. 2006. Fluorescence microscopy for studying the viability of micro-organisms in natural whey starter. Lett. Appl. Microbiol. 42:338-343.

Giraffa, G., G. Mucchetti, F. Addeo, and E. Neviani. 1997. Evolution of lactic acid microflora during Grana cheese-making and ripening. M. A. N. 15:115-122.

Gómez Zavaglia, A., E. A. Disalvo, and G. L. De Antoni. 2000. Fatty acid composition and freeze-thaw resistance in lactobacilli. J. Dairy Res. 67:241-247.

Gouesbet, G., G. Jan, and P. Boyaval. 2002. Two-dimensional electrophoresis study of Lactobacillus delbrueckii subsp. bulgaricus thermotolerance. Appl. Environ. Microbiol. 68:1055-1063.

Guerzoni, M. E., R. Lanciotti, and P. S. Cocconcelli. 2001. Alteration in cellular fatty acid composition as a response to salt, acid, oxidative and thermal stresses in Lactobacillus helveticus. Microbiol. 147:2255-2264

Head, I. M., J. R. Saunders, and R. W. Pickup. 1998. Microbial evolution, diversity, and ecology: A decade of ribosomal RNA analysis of uncultured microorganisms. Microb. Ecol. 35:1-21.

Hori, T., S. Haruta, Y. Ueno, M. Ishii, and Y. Igarashi. 2006. Direct comparison of single-strand conformation polymorphism (SSCP) 
and denaturing gradient gel electrophoresis (DGGE) to characterize a microbial community on the basis of $16 \mathrm{~S}$ rRNA gene fragments. J. Microbiol. Met. 66:165-169.

Kim, W. S., and N. W. Dunn. 1997. Identification of a cold shock gene in lactic acid bacteria and the effect of cold shock on cryotolerance. Curr. Microbiol. 35:59-63.

Lazzi, C., L. Rossetti, M. Zago, E. Neviani, and G. Giraffa. 2004. Evaluation of bacterial communities belonging to natural whey starters for Grana Padano cheese by length heterogeneity-PCR. J. Appl. Microbiol. 96:481-490.

Marsh, T. L. 1999. Terminal restriction fragment length polymorphism (T-RFLP): An emerging method for characterizing diversity among homologous populations of amplification products. Curr. Opin. Microbiol. 2:323-327.

Mucchetti, G., and E. Neviani. 2006. Microbiologia e tecnologia lattierocasearia. Qualità e sicurezza, ed. Tecniche nuove, Milano, Italy.

Osborn, A. M., E. R. B. Moore, and K. N. Timmis. 2000. An evaluation of terminal-restriction fragment length polymorphism (T-RFLP) analysis for the study of microbial community and dynamics. Environ. Microbiol. 2:39-50.

Ritchie, N. J., M. E. Schutter, R. P. Dick, and D. D. Myrold. 2000. Use of length heterogeneity PCR and fatty acid methyl ester profiles to characterize microbial communities in soil. Appl. Environ. Microbiol. 66:1668-1675.

Sánchez, J. I., L. Rossetti, B. Martínez, A. Rodríguez, and G. Giraffa. 2006. Application of reverse transcriptase PCR-based T-RFLP to perform semi-quantitative analysis of metabolically active bacteria in dairy fermentations. J. Microbiol. Methods 65:268-277.

Sheehan, J. J., M. A. Fenelon, M. G. Wilkinson, and P. L. H. McSweeney. 2007. Effect of cook temperature on starter and nonstarter lactic acid bacteria viability, cheese composition and ripening indices of a semi-hard cheese manufactured using thermophilic cultures. Int. Dairy J. 17:704-716.

Suzuki, M. T., M. S. Rappe, and S. J. Giovannoni. 1998. Kinetic bias in estimates of coastal picoplankton community structure obtained by measurements of small-subunit rRNA gene PCR amplicon length heterogeneity. Appl. Environ. Microbiol. 64:4522-4529.

van de Guchte, M., P. Serror, C. Chervaux, T. Smokvina, S. D. Ehrlich, and E. Maguin. 2002. Stress responses in lactic acid bacteria. Antonie Leeuwenhoek 82:187-216.

Varcamonti, M., S. Arsenijevic, L. Martinari, D. Fusco, G. Naclerio, and M. De Felice. 2006. Expression of the heat shock gene $\operatorname{clpL}$ of Streptococcus thermophilus is induced by both heat and cold shock. Microb. Cell Fact. 5:1-6.

Wolffs, P., B. Norling, and P. Rådström. 2005. Risk assessment of false-positive quantitative real-time PCR results in food, due to detection of DNA originating from dead cells. J. Microbiol. Methods 60:315-323.

Wouters, J. A., F. M. Rombouts, W. M. De Vos, O. P. Kuipers, and T. Abee. 1999. Cold shock proteins and low-temperature response of Streptococcus thermophilus CNRZ302. Appl. Environ. Microbiol. 65:4436-4442. 